\title{
Identifying the most productive breeding sites for malaria mosquitoes in The Gambia \author{
Willem Takken ${ }^{2}$ and Steven W Lindsay ${ }^{1}$
} \\ Ulrike Fillinger*1, Heleen Sombroek ${ }^{2,3}$, Silas Majambere ${ }^{4}$, Emiel van Loon ${ }^{3}$,
}

\begin{abstract}
Address: ${ }^{1}$ Disease Control \& Vector Biology Unit, London School of Hygiene and Tropical Medicine, Keppel Street, London, WC1E 7HT, UK, ${ }^{2}$ Laboratory of Entomology, Wageningen University, 6709 PD Wageningen, The Netherlands, ${ }^{3}$ Institute for Biodiversity and Ecosystem Dynamics, University of Amsterdam, Nieuwe Achtergracht 166, 1018 WW Amsterdam, The Netherlands and ${ }^{4}$ Ifakara Health Institute, PO Box 78373, Dar es Salaam, Tanzania

Email: Ulrike Fillinger* - ulrike.fillinger@lshtm.ac.uk; Heleen Sombroek - h.sombroek@gmail.com; Silas Majambere - smajambere@ihi.or.tz; Emiel van Loon - vanloon@uva.nl; Willem Takken - willem.takken@wur.nl; Steven W Lindsay - s.w.lindsay@durham.ac.uk

* Corresponding author
\end{abstract}

Published: 10 April 2009

Malaria Journal 2009, 8:62 doi:10.1 /86/1475-2875-8-62

This article is available from: http://www.malariajournal.com/content/8/I/62

(C) 2009 Fillinger et al; licensee BioMed Central Ltd.

This is an Open Access article distributed under the terms of the Creative Commons Attribution License (http://creativecommons.org/licenses/by/2.0), which permits unrestricted use, distribution, and reproduction in any medium, provided the original work is properly cited.
Received: 6 January 2009

Accepted: 10 April 2009

\begin{abstract}
Background: Ideally larval control activities should be targeted at sites that generate the most adult vectors, thereby reducing operational costs. Despite the plethora of potential mosquito breeding sites found in the floodplains of the Gambia River, about $150 \mathrm{~km}$ from its mouth, during the rainy season, only a small proportion are colonized by anophelines on any day. This study aimed to determine the characteristics of larval habitats most frequently and most densely populated by anopheline larvae and to estimate the numbers of adults produced in different habitats.

Methods: A case-control design was used to identify characteristics of sites with or without mosquitoes. Sites were surveyed for their physical water properties and invertebrate fauna. The characteristics of 83 sites with anopheline larvae (cases) and 75 sites without (controls) were collected between June and November 2005. Weekly adult productivity was estimated with emergence traps in water-bodies commonly containing larvae.

Results: The presence of anopheline larvae was associated with high invertebrate diversity (Odds Ratio, OR II.69, 95\% Cl 5.6I-24.34, p < 0.00I), the presence of emergent vegetation (OR 2.83, 95\% Cl I.35-5.95, $\mathrm{p}=$ 0.006 ), and algae (at borderline significance; OR I.87, 95\% Cl 0.96-3.6I8, $\mathrm{p}=0.065$ ). The density of larvae was reduced in sites that were larger than $100 \mathrm{~m}$ in perimeter (OR $0.15 \mathrm{I} ; 95 \% \mathrm{Cl} 0.060-0.38 \mathrm{I}, \mathrm{p}<0.00 \mathrm{I}$ ), where water was tidal (OR $0.232 ; 95 \% \mathrm{Cl} 0.10 \mathrm{I}-0.533, \mathrm{p}=0.00 \mathrm{I})$, vegetation shaded over $25 \%$ of the habitat (OR 0.352 ;

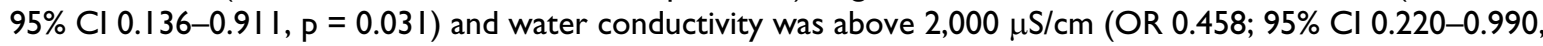
$\mathrm{P}=0.048$ ). Pools produced the highest numbers of Anopheles gambiae adults compared with rice fields, floodwater areas close to the edge of the floodplain or close to the river, and stream fringes. Pools were characterized by high water temperature and turbidity, low conductivity, increased presence of algae, and absence of tidal water.

Conclusion: There are few breeding sites that produce a high number of adult vectors in the middle reaches of the river in The Gambia, whereas those with low productivity are larger in area and can be found throughout the rainy season. Even though risk factors could be identified for the presence and density of larvae and productivity of habitats, the results indicate that anti-larval interventions in this area of The Gambia cannot be targeted in space or time during the rainy season.
\end{abstract}




\section{Background}

Larval source management (LSM), a strategy which includes larviciding and source reduction (environmental manipulation, modification and elimination of aquatic habitats) for mosquito larval control, has long been used as a measure for malaria control in many parts of the tropics [1-7]. More recently larval control has been shown to be highly effective at reducing malaria transmission in Eritrea $[8,9]$, Kenya [10,11] and Tanzania [12,13]. These studies were all carried out in sites with well-defined breeding sites that were not too extensive. However, it is not known whether this approach will be effective in areas where breeding sites cover large areas, as in the floodplains of large rivers or lakes. The work presented here is part of a series of studies recently undertaken in the The Gambia to determine whether larviciding with microbials [14] can reduce malaria transmission in an area of extensive seasonal flooding and to design rational application strategies for operational implementation.

In The Gambia, the landscape is dominated by the river and its floodplains dividing the small country into the river's north and south bank. Seasonal flooding creates large areas of water for extended periods of time and provides potential breeding sites for mosquitoes including the primary and secondary malaria vectors Anopheles gambiae, Anopheles arabiensis, Anopheles melas, Anopheles funestus, Anopheles coustani and Anopheles pharaoensis [15]. In The Gambia, malaria transmission is highly seasonal and peaks at the end of the rainy season which typically takes place from June to October $[16,17]$. In the middle reaches of the river in The Gambia (approximately $150 \mathrm{~km}$ from its mouths) there is considerable local variation in malaria intensity between villages. Malaria prevalence in children ranges between 5-90\% [16,17] and the average entomological inoculation rate (EIR) between 0-150 infective bites per person per year [18].

The national strategy for malaria control in the country includes mosquito larval control [19], yet there has been no detailed evaluation of this methodology until now. The common malaria vectors in The Gambia are highly susceptible to commercial formulations of microbial larvicides in laboratory and field trials but the larvicides failed to exhibit any residual effect, which means that weekly applications are necessary to prevent adult mosquito emergence [14].

Mapping of all aquatic habitats in a study area of $400 \mathrm{~km}^{2}$ was implemented under operational conditions [20] as a pre-requisite for successful anti-larval interventions $[12,21]$ This was done to guide the larval control programme and determine whether specific habitat characteristics were associated with the presence of anopheline larvae [20]. It was hoped that any such characteristics could be used to guide interventions to target LSM at specific sites to reduce the logistics and costs necessary to implement larviciding at weekly intervals. The mapping revealed [20] a large number of shallow water bodies during the rainy season, primarily in the floodplains. The risk of finding anophelines increased in habitats located within the first one $\mathrm{km}$ stretch of the floodplains, from the landward edge towards the river. These were large in size and located in areas where grassy vegetation (including rice and sedge) dominated the land cover. Unfortunately, over $80 \%$ of all habitats shared similar features and these could not be used as criteria to help target anti-larval interventions. Thus, the type of water body and the habitat in which they were located could not be used for identifying sites for targeted LSM. Nevertheless, at any time of the year, only a small percentage of aquatic habitats actually contained mosquito larvae [20] suggesting that other criteria than those surveyed under operational conditions may be responsible for habitat colonization and productivity, such as microclimate, water quality and interactions with other aquatic organisms.

This experimental study was carried out to determine whether a detailed ecological and physical characterization of anopheline habitats could explain differences not only in vector colonization but also in larval density and, more importantly, densities of emerging adults in order to determine whether larval control can be targeted at particular sites [22].

\section{Methods \\ Study area}

The Gambia is a small, narrow country in West Africa whose borders mirror the meandering Gambia River. The country is less than $48 \mathrm{~km}$ wide, with a total area of $11,300 \mathrm{~km}^{2}$. The study was done on the north bank of the Gambia River, east of Farafenni town, around Balanghar Ker Nderry (UTM: 1510598N, 456756E) from June to November 2005 during the rainy season, the peak season of malaria transmission. Mosquito collections were carried out within an area of approximately $100 \mathrm{~km}^{2} \mathrm{com}-$ prising the most common habitats found in the large river ecosystem $[14,20]$. The study area can be divided broadly into: (1) upland that is predominantly woodland savannah and farmland, where the main crops are millet and groundnuts, and (2) the river's floodplain, where large areas of alluvial soils are flooded during the rainy season and rice is grown.

\section{Habitat surveys}

Our aim in the present study was to identify the characteristics of habitats with larvae, as well as those with the highest densities. Our surveys differed in a number of aspects from previously published work implemented under operational conditions [20]. Firstly, in this case, as 
with most larval surveys, sites were not selected randomly in space and time and are therefore subject to potential confounding. The case-control approach we adopted here allowed us to randomly select sites in space and time. Secondly, we used area samplers, a more accurate sampling tool for collecting larvae, than standard dippers when larval densities are low [14]. Thirdly, water chemistry and associated insect fauna was analyzed in association with larval abundance.

At the end of each week, records from the routine habitat surveillance were used to identify habitats that contained anopheline larvae in the last five days. This routine surveillance was implemented in preparation for a large-scale larviciding trial with the aim to map all available water bodies within the area every four to six weeks [20]. Each habitat's position was recorded with a handheld Global Positioning System (GPS, Garmin GPS 12 XL, 15 metres accuracy), received a unique habitat number and information on the presence and absence of mosquito larvae was noted. More details on the methodology have been described by Majambere and others [20]. Of all habitats surveyed the previous week, five sites colonized by Anopheles larvae and five sites where no Anopheles larvae were found, were selected randomly (irrespective of other habitat characteristics) without replacement using the webbased randomization tool [23]. These sites were surveyed intensively the following week as described below.

In each aquatic habitat, three samples of mosquitoes and other organisms present were taken with an area sampler

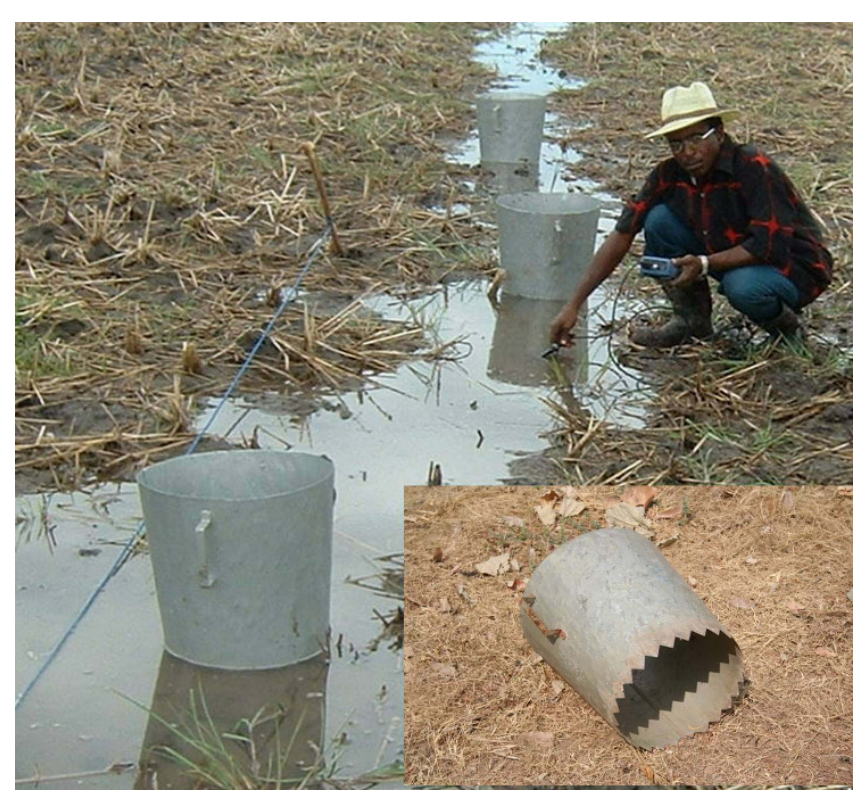

Figure I

Area samplers for sampling aquatic fauna.
(AS; Figure 1) [24] within $10 \mathrm{~m}$ of each other. Samples within each sampling site were pooled. The AS was a 39.5 $\mathrm{cm}$ long aluminium tube, with serrated teeth around the bottom lip to grip into the substrate. It had an upper diameter of $47 \mathrm{~cm}$ and a lower one of $40 \mathrm{~cm}$ sampling a surface area of $0.126 \mathrm{~m}^{2}$. The AS was plunged quickly into the water body in areas most likely to contain larvae (i.e. edge of water or near emergent vegetation [25]) and left for 30 seconds to allow the water to settle and larvae to come to the surface. A standard $350 \mathrm{ml}$ dipper was used to empty the water from the AS and transfer it into a white plastic bowl containing clear water. Excess water was carefully removed to concentrate any organisms present in the bowl. All invertebrates were collected and placed in 98\% ethanol before being transported to the laboratory for identification. All insects, excluding mosquitoes, were separated into the following taxonomic groups: beetle larvae (Coleoptera), bettle adults (Coleoptera), dragonfly and damselfly larvae (Odonata; sub-order Anisoptera and Zygoptera), mayfly larvae (Ephemeroptera), larvae of the Diptera families of non-biting midges (Chironomidae) and phantom midges (Chaoboridae) and water bugs (Heteroptera), which were further identified as broadshouldered water striders (Veliidae), creeping water bugs (Noucoridae), greater water boatman (Notonectidae), lesser water boatman (Corixidae), pigmy backswimmers (Pleidae), pond skaters (Gerridae), water measurers (Hydrometridae) and water scorpion (Nepidae). Mosquito larvae were identified and counted as anopheline and culicine early ( $1^{\text {st }}$ and $2^{\text {nd }}$ stage larvae) and late instars (3rd and $4^{\text {th }}$ stage larvae). Mosquitoes were identified on morphological characteristics, and members of the An. gambiae complex identified to species level by PCR analysis [26].

The presence of small fish and any vegetation present inside the AS was recorded. The presence of algae was confirmed by microscopic investigation of a water sample or the presence of filamentous algal mats. Each aquatic habitat was classified into one of the following categories (presenting the full diversity of aquatic habitats within the study area) which are usually found in succession from the village (upland) towards the main river (floodplains): (1) Brick or sand pits: borrow pits ( $>2 \mathrm{~m}$ diameter) resulting from brick-making or other construction activities, (2) Pools: discrete $(<200 \mathrm{~m}$ diameter) and shallow $(<50 \mathrm{~cm})$ standing water bodies, usually drying out towards the end of the dry season, (3) Edges of floodwater: the shallow landward edges of the extensive floodwater in the floodplains of the river or its tributaries, usually associated with grass (Paspalum and Sporobolus sp.) and sedge (Eleocharis sp.), (4) Ponds: discrete and permanent water bodies, more than $100 \mathrm{~m}$ in circumference fed by groundwater and deeper than pools, (5) Water channels: used for irrigation or drainage, (6) Stream fringes: the shallow edges 
of permanent streams associated with grass or sedge, and tall reeds in deeper parts, (7) Puddles or tyre tracks: small natural or vehicle-made depressions, (8) Floodwater: inundated areas in the floodplain further away from the landward edge, towards the river, (9) Rice fields: seasonally flooded areas used to grow rice, and (10) Mangrove: water body characterized by densely growing mangrove trees (Rhizophora and Avicennia sp.) near the main river.

\section{Emergence trap collections}

Data on mosquito adult emergence were collected in order to investigate the relative productivity of different habitats where larvae were frequently found. The extensive mapping of the study area in preparation for a large operational larval control trial showed that anopheline larvae occurred in a variety of habitats, even close to the river [20]. The baseline data also indicated that rice fields, floodwater areas with sedge and/or grass, stream fringes (water covering grassy edge) and pools were among the most commonly encountered aquatic habitats and were to a high proportion colonized by anopheline larvae [20]. The objective was to evaluate whether these habitats are equally productive in terms of adult emergence and to assess if distance to the river affects the larval development to adult stage. Here, the number of adults that emerged from any breeding site served as an indicator of risk of malaria transmission but other factors such as the size of emerging adults may also be important.

Therefore, six areas were selected were the following habitats dominated respectively: (1) a collection of pools within the floodplain, (2) stream fringes within the floodplain, (3) rice fields at the edge of the floodplain, (4) rice fields close to the river, (5) floodwater areas (sedge/grass) at the edge of the floodplains, and (6) floodwater areas within the floodplains. These areas were chosen randomly from sites that contained Anopheles larvae at least once during the rainy season in 2004. Six floating emergence traps [27] were positioned in each of these habitats to sample adult insects continuously from June to November 2005 (Figure 2). These traps collected positively phototaxic arthropods that emerged from the water. Traps were positioned over water thought likely to contain anopheline larvae (e.g. at the edges of the habitat, over tuft of vegetation). Each trap was at least $50 \mathrm{~m}$ from its nearest neighbour. They were constructed from conical metal frames $1 \mathrm{~m}$ in height and $1 \mathrm{~m}$ in diameter $\left(0.786 \mathrm{~m}^{2}\right.$ surface area) and covered in synthetic netting to reduce shading of the water, which might reduce invertebrate catches. Traps were made buoyant by attaching plastic $1 \mathrm{~L}$ bottles to the base with wire to allow the water to flow undisturbed under the trap, maintaining current, ambient temperature and oxygen, and other biotic and abiotic factors. Bottles were partly filled with sand to prevent the trap from being blown over by strong winds. Each trap was

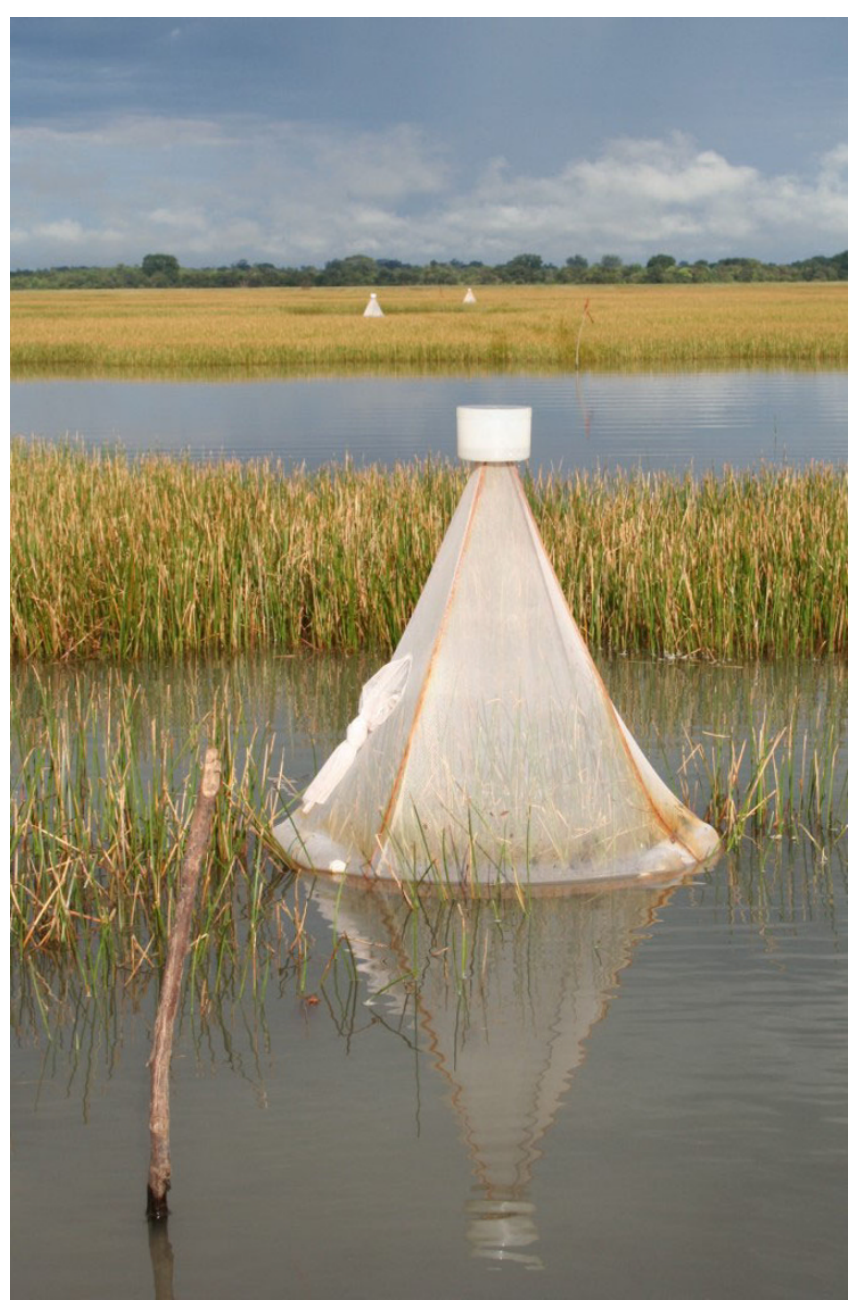

Figure 2

Emergence traps used for estimating adult vector production per habitat type.

tethered with a length of rope to a wooden stake anchored to the ground allowing the trap to rotate freely. Traps placed over mature rice plants were not tethered.

The top of each cone opened into a plastic insect collection chamber (Bioform, Germany) with a transparent polystyrol lid. The chambers were filled with $250 \mathrm{ml}$ of $60 \%$ glycol in order to kill and preserve flying insects that collected there. A netting sleeve on the side of each trap allowed flying insects caught within the netting cone to be removed with an aspirator. Traps were emptied weekly and specimens transported to the laboratory for identification. The dominant vegetation in and around the traps was recorded weekly as: (1) grass including rice (Paspalum, Sporobolus sp. or Oryza sativa), (2) sedge (Eleocharis sp.), (3) sea-purslane (Sesuvium sp.), (4) reeds (Cyperus papyrus and Phragmites karka), (5) algae (filamentous and singlecelled), (6) floating plants e.g. Azolla sp., water-lilies or (7) 
no vegetation. After collection, the chambers and traps were cleaned of spiders and webs and other detritus which might lead to over- or underestimation of catch size. Traps were moved weekly to a new position within $10 \mathrm{~m}$ from the previous sampling point.

In the laboratory, the content of each collection chamber was filtered to remove the glycol and transferred to ethanol. Insects were classified into the following taxons: beetles (Coleoptera), dragon- and damselflies (Odonata); mayflies (Ephemeroptera), and water bugs (Corixidae, Hydrometridae, Nepidae, Notonectidae, or Noucoridae). Within the order Diptera the sub-order Brachycera were separated from the sub-order Nematocera. The latter were classified as phantom midges (Chaoboridae), non-biting midges (Chironomidae), blackflies (Simuliidae) or mosquitoes (Culicidae). Mosquitoes were identified and counted as anopheline and culicine males and females. All insects were identified with the aid of morphological keys and members of the An. gambiae complex identified by PCR analysis [26].

\section{Water physical measurements}

Water measurements were made at each survey point. Water depth was measured with a measuring tape at three different locations within the sampling area and averaged. Whether the water was tidal or not was assessed visually. The overall perimeter size of the habitat was estimated as: (1) $<10 \mathrm{~m}$, (2) 10-100 $\mathrm{m}$ or (3) $>100 \mathrm{~m}$. In large areas of water it was also recorded whether the water outside the sampling area was deeper $(>50 \mathrm{~cm})$ than the area where samples were taken. The coverage of the water surface with tall emergent vegetation was visually estimated as: (1) $<25 \%$, (2) 25-50\%, (3) 51-75\%, and (4) >75\%. Water conductivity, $\mathrm{pH}$, temperature and dissolved oxygen content were measured with a multiparameter probe (350i WTW, Germany) and water turbidity with a turbidity meter (HANNA, USA). Measurements were made weekly at all larval survey points and in the areas of adult sampling. All samples were taken between 07:00 and 14:00 hrs.

\section{Statistical analysis}

Proportions were compared using likelihood ratio chisquare analysis. Comparisons between means of normally distributed data were made using students t-test or oneway ANOVA in combination with a Gabriel post-hoc test. Means of data that could not be normalized were compared using the Kruskall-Wallis Test. The Bonferroni correction was used where applicable. The number of insect taxa was counted and the Shannon index (taking into account the number of identified taxa as listed above and their proportion in a sample) was used as a metric for species diversity [28]. Risk factor analyses were implemented using Generalized Estimating Equations (GEE) [29]. Variables were incorporated untransformed in the model and their impact on the presence or absence and on the density of anopheline larvae or adults tested. Binary data (presence or absence) was fitted to a binomial distribution with a logit link function. Count data were fitted to a negative binomial distribution with a log link function. GEE were also used to calculate mean Anopheles larval and adult densities, with site ID as subject units, log linked mosquito densities and habitat type as the factor. A stepwise backwards approach was used for the final models. Analyses were performed with SPSS version 15. Data from emergence traps that were not fully working were excluded from the analysis.

\section{Results}

\section{Presence or absence of larvae}

Between June and November 2005 data from 83 sites with anopheline larvae (cases) and 75 sites without (controls) were collected. Most sites were in the floodplains (81.6\%) and a smaller sample in the uplands (18.4\%). All major habitat types identified by Majambere and others [20] were represented in the random samples (Table 1).

A total of 5,784 invertebrates and 195 fish were collected from the 158 sites sampled. Culicid larvae were the most abundant organisms with 708 anopheline larvae $(60 \%$ early and 40\% late instars) and 3,868 culicine larvae (52\% early and $48 \%$ late instars). Notably, only 15 anopheline

Table I: Habitat types surveyed for absence (controls) and presence (cases) of Anopheles larvae

\begin{tabular}{llrr}
\hline & Habitat type & Controls $(\mathbf{n}=\mathbf{7 5})$ & Cases $(\mathbf{n}=\mathbf{8 3})$ \\
\hline \multirow{2}{*}{ Upland } & Puddles & 2 & 3 \\
& Man-made pits & 3 & 4 \\
& Pools & 0 & 8 \\
& Ricefields & 0 & 2 \\
\hline \multirow{2}{*}{ Floodplain } & Puddles & 1 & 3 \\
& Pools & 6 & 7 \\
& Stream fringes & 7 & 15 \\
& Ricefields & 17 & 19 \\
& Floodwater & 32 & 22
\end{tabular}


pupae and 18 culicine pupae were caught in the area samplers. Among the predatory insects the lesser water boatman $(n=761)$ and greater water boatman $(n=187)$ were most abundant. Other water bugs $(n=20)$ included water measurers, pond skaters, water scorpions and creeping water bugs. In addition, 60 damselflies, 46 dragonflies, 32 beetle larvae and 51 beetle adults were collected. Only 4 chironomid larvae were collected in the area samplers probably because most species live within the sediment.

Comparison of cases and controls showed that the two groups were similar in most of their characteristics (Table 2). A similar proportion of habitats selected in both groups were tidal and deep and contained fish. The mean water depths, vegetation cover, water temperature at sampling time, $\mathrm{pH}$, salinity, turbidity and oxygen saturation were also similar in the two groups. Only two characteristics were significantly different; anopheline larvae were found where there was high insect diversity and where water conductivity was low.

Stepwise backwards binary logistic regression (entered at first step: habitat type, habitat size, habitat depth, water body depth, percentage vegetation cover, presence of tidal water, type of emergent vegetation and presence of algae) revealed that the presence of Anopheles larvae was only associated with the presence of emergent vegetation (Odds Ratio, OR $=2.83,95 \%$ Confidence intervals, CI $1.35-5.95, \mathrm{p}=0.006$ ) and algae (OR 1.87, 95\% CI 0.96$3.618, \mathrm{p}=0.065)$; however the latter only approached statistical significance. Similarly, the diversity of other organ- isms increased in the habitat when emergent vegetation (OR 1.88; 95\% CI 1.23-2.89, p = 0.004) and algae (OR $1.87,95 \%$ CI 1.40-2.49, p < 0.001) were present. Consequently, there was a highly significant association between the presence of Anopheles larvae and the diversity index (OR 11.69, 95\% CI 5.61-24.34, p < 0.001). The impact of increasing conductivity on biological outcome measures was not clear-cut. Regression analyses did not reveal any significant associations between groups of increasing conductivity and the presence of Anopheles larvae. This might be due to the fact that the relationship between the variables was not linear.

There was only a very weak correlation between the presence of early and late instar larvae $\left(\mathrm{r}^{2}=0.095 ; \mathrm{p}=0.005\right)$. Early instars were found in $88 \%(73 / 83)$ of cases whilst late instars were only recorded in 59\% (49/83). Both stages together occurred in only $47 \%$ of all cases $(39 / 83)$. Therefore, binary analyses for both sub-groups were run separately. When modelling the risk factors associated with the presence of early instar anophelines in a stepwise backwards approach the likelihood of finding early instars was significantly higher when samples were taken in areas where the water was less than $10 \mathrm{~cm}$ deep (OR 11.00, 95\% CI 1.23-98.60, $\mathrm{p}=0.032$ ) and in water-bodies that contained emergent vegetation (OR 2.86, 95\% CI 1.32-6.20, $\mathrm{p}=0.008$ ) and algae (OR 2.36, 95\% CI 1.18-4.72, $\mathrm{p}=$ $0.015)$. For late instars only the presence of vegetation (OR 2.07, 95\% CI 0.90-4.76, $\mathrm{p}=0.089$ ) and algae (OR $1.92,95 \%$ CI $0.96-3.83, \mathrm{p}=0.065)$ remained in the final model. Both factors only approached significance.

Table 2: Descriptive statistics for habitats without (controls) and with (cases) Anopheles larvae

\begin{tabular}{|c|c|c|c|c|}
\hline & Control & Cases & $\mathbf{p}$ & $\chi^{2 / t}$ \\
\hline \multicolumn{5}{|l|}{ PROPORTION* } \\
\hline of tidal water bodies & $72.0 \%$ & $74.7 \%$ & 0.701 & 0.147 \\
\hline of deep waterbodies $(>50 \mathrm{~cm})$ & $25.3 \%$ & $22.9 \%$ & 0.720 & 0.129 \\
\hline of habitats with fish & $20.0 \%$ & $14.5 \%$ & 0.355 & 0.854 \\
\hline of habitats with Culicinae & $20.0 \%$ & $53.0 \%$ & $<0.001$ & $|8.35|$ \\
\hline of habitats with Odonata & $14.7 \%$ & $38.6 \%$ & 0.001 & 11.349 \\
\hline of habitats with Coleoptera larvae & $12.0 \%$ & $27.7 \%$ & 0.014 & 6.021 \\
\hline of habitats with Coleoptera adults & $24.0 \%$ & $39.8 \%$ & 0.034 & 4.476 \\
\hline of habitats with Ephemeropera & $5.4 \%$ & $20.5 \%$ & 0.005 & 7.845 \\
\hline of habitats with Heteroptera & $26.7 \%$ & $49.4 \%$ & 0.003 & 8.589 \\
\hline \multicolumn{5}{|l|}{ MEAN $(95 \% \mathrm{CI}) * *$} \\
\hline Diversity index & $0.27(0.18-0.35)$ & $0.85(0.73-0.97)$ & $<0.001$ & 7.898 \\
\hline Water depths $(\mathrm{cm})$ & $7.2(5.5-8.9)$ & $7.0(5.6-8.5)$ & 0.871 & 0.163 \\
\hline Vegetation cover of habitats (\%) & $50.3(42.4-58.3)$ & $48.6(41.7-55.5)$ & 0.745 & 0.326 \\
\hline Water temperature $\left({ }^{\circ} \mathrm{C}\right)$ & $30.4(29.6-31.3)$ & $29.4(28.5-30.3)$ & 0.111 & 1.044 \\
\hline $\mathrm{pH}$ & $6.4(6.2-6.6)$ & $6.5(6.3-6.7)$ & 0.373 & -0.894 \\
\hline Conductivity $(\mu \mathrm{S} / \mathrm{cm})$ & 7009 (4700-9319) & $3621(2331-4911)$ & 0.010 & 2.609 \\
\hline Turbidity (ntu) & $136.9(86.6-187.3)$ & $191.4(\mid 28.4-254.4)$ & 0.188 & -1.323 \\
\hline Oxygen saturation (\%) & $72.4(63.1-81.8)$ & $83.2(72.5-93.8)$ & 0.133 & -1.509 \\
\hline
\end{tabular}

*Proportions are compared using $\chi^{2}$-test

**Means are compared using t-test 
Of 708 anopheline larvae sampled, 166 larvae were identified to species level. An. arabiensis accounted for $37.3 \%$ of anophelines, An. gambiae s.s. for 4.8\%, An. melas for 4.2\% (total of An gambiae s.l. 46.3\%), An. coustani s.l. for 31.9\% (this includes An. coustani and Anopheles ziemanni, two species which can not be morphologically distinguished in the larval stage and were therefore grouped together throughout and referred to as An. coustani s.l. hereafter), An. pharaoensis for $11.4 \%$ and the remaining $10.2 \%$ were other anopheline species. Anopheline larvae were found in all habitat types surveyed. Whereas floodwater areas, rice fields and stream fringes were dominated by An. coustani s.l. and to a lesser extent by An. pharaoensis, pools, puddles and man-made pits were predominantly colonized by An. gambiae s.l.. An. arabiensis was the most common member of the An. gambiae complex and was the only species found in rice fields (Table 3).

\section{Larval density}

The mean number of Anopheles larvae per $\mathrm{m}^{2}$ (considering cases only) was 22.6 (95\% CI 11.6-33.5) during the study; early instars accounted for $60 \%$ of all larvae (13.5, 95\% CI 6.7-20.3) and late instars for 40\% (9.1, 95\% CI 1.9-16.2). At the beginning of the rainy season in June/ July mosquito larval densities were low and predatory invertebrates (e.g. beetles, dragon-and damselflies, water bugs) largely absent. Anopheles densities per $\mathrm{m}^{2}$ were highest at the beginning of August and the end of September. Culicine mosquitoes were most abundant at the end of the rainy season (Figure 3).

Larval densities for each habitat type in the upland and floodplains of the River Gambia were highly variable (Table 4). Upland sites had a greater larval density (OR $2.70,95 \%$ CI 1.05-6.98, $\mathrm{p}=0.04)$, but adjusting for hab- itat type, this association was not significant indicating that high larval density is dependent on the habitat type or more importantly the characteristics associated with this habitat type, but not location. High larval densities were found in puddles $(n=3)$ and man-made pits in the upland $(n=4)$ and pools in the floodplains $(n=7)$. Floodplain pools had not only significantly higher larval densities than upland pools $(n=8)$ but all other habitat types sampled in the floodplain (Table 4).

Whilst the presence or absence of anopheline larvae was associated with the presence of vegetation or algae, the density of larvae was dependent on a variety of physical factors. Larval density decreased with: (1) increasing size of habitats, (2) increasing vegetation cover shading the habitat, (3) the presence of tidal water and (4) when the water body as a whole was on average deeper than $50 \mathrm{~cm}$ (Table 5). There was no difference for early and late instars. The water depth, presence of vegetation or algae at the sampling point, the presence or abundance of fish, or the increase in the diversity index were not significantly associated with anopheline larval density, neither with early nor late instars nor any specific Anopheles species.

Increased water conductivity was associated with lower larval densities. Conductivity values above $2000 \mu \mathrm{S} / \mathrm{cm}$ lead to significant reductions (OR 0.458 ; 95\% CI $0.212-$ $0.990, \mathrm{p}=0.047$ ), although this relationship was species dependent. Whilst An. gambiae s.s. and An. arabiensis were negatively affected by high salinity as estimated by conductivity (OR 0.206, 95\% CI 0.080-0.531, p = 0.001), no association was found for An. coustani s.l., An. melas and An. pharaoensis. The $\mathrm{pH}$ varied very little between habitats (Table 2) and was not associated with larval density; neither was turbidity nor oxygen saturation.

Table 3: Anopheles larvae species composition per habitat type

\begin{tabular}{|c|c|c|c|c|c|c|c|c|c|}
\hline \multirow[t]{2}{*}{ Habitat type } & \multirow{2}{*}{$\begin{array}{r}\text { Total number } \\
\text { of } \\
\text { larvae sampled }\end{array}$} & \multirow{2}{*}{$\begin{array}{r}\text { Proportion of } \\
\text { larvae } \\
\text { identified in \% } \\
(n)\end{array}$} & \multicolumn{7}{|c|}{ Anopheles species composition based on identified specimen in $\%$} \\
\hline & & & gambiae s.l. & gambiae s.s.* & arabiensis* & melas* & coustani & pharaoensis & others \\
\hline $\begin{array}{r}\text { Floodwater } \\
(\mathrm{n}=22)\end{array}$ & 95 & $\begin{array}{l}34.7 \\
(33)\end{array}$ & 21.2 & 6.1 & 0.0 & 15.2 & 30.3 & 18.2 & 30.3 \\
\hline $\begin{array}{r}\text { Rice field } \\
(n=2 I)\end{array}$ & 71 & $\begin{array}{l}32.4 \\
(23)\end{array}$ & 17.4 & 0.0 & 17.4 & 0.0 & 47.8 & 8.7 & 26.1 \\
\hline $\begin{array}{l}\text { Stream fringe } \\
(\mathrm{n}=15)\end{array}$ & 76 & $\begin{array}{l}39.5 \\
(30)\end{array}$ & 10.0 & 6.7 & 3.3 & 0.0 & 53.3 & 20.0 & 16.7 \\
\hline $\begin{array}{r}\text { Pool } \\
(n=15)\end{array}$ & 213 & $\begin{array}{l}21.1 \\
(45)\end{array}$ & 53.3 & 6.7 & 46.7 & 0.0 & 28.9 & II.I & 6.7 \\
\hline $\begin{array}{l}\text { Puddle } \\
(\mathrm{n}=6)\end{array}$ & 158 & $\begin{array}{l}20.3 \\
(32)\end{array}$ & 87.5 & 3.1 & 81.3 & 3.1 & 6.3 & 0.0 & 6.3 \\
\hline $\begin{array}{r}\text { Man-made pits } \\
(\mathrm{n}=4)\end{array}$ & 95 & $\begin{array}{l}16.8 \\
(16)\end{array}$ & 87.5 & 6.3 & 75.0 & 6.3 & 0.0 & 0.0 & 12.5 \\
\hline
\end{tabular}

\footnotetext{
*species of the An. gambiae complex summarized under An. gambiae s.l.
} 


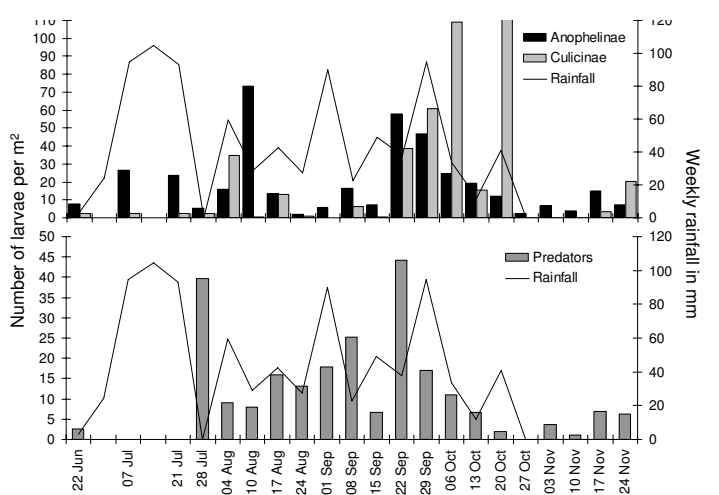

Figure 3

Weekly average density of mosquito larvae and predatory insects per $\mathbf{m}^{2}$ in relation to rainfall pattern.

\section{Emergence}

A total of 106,234 insects were caught in the emergence traps in 715 trap-weeks. Dipterans represented 99\% $(105,204)$ of the catch, the remaining $1 \%$ were dragonand damselflies (434) and waterbugs (596) (Table 6). Most Diptera were non-biting midges (Chironomidae, $85 \%$ ), culicine mosquitoes represented $7.3 \%$ and anopheline mosquitoes $0.3 \%$. Members of the An. coustani group were the dominant anopheline species (66\%) caught. An. gambiae s.l. accounted only for $23 \%$ of the emerged anophelines and An. pharaoensis for 4\% (13). The remaining $7 \%$ of anophelines could not be identified. After one week of storage in glycol under very hot conditions insect samples were often in bad condition when returned to the laboratory and therefore only 25 specimen of the An. gambiae s.l. sample could be successfully amplified for PCR analyses. Similar to the larval catches, An. arabiensis was the dominant species of the gambiae-complex (68\%), followed by An. gambiae s.s. (20\%) and An. melas (12\%).

Table 4: Mean (95\% Cl) Anopheles larval densities in habitats upland and in the floodplain

\begin{tabular}{rrrr}
\hline & Upland & Floodplain & $\mathbf{p}^{*}$ \\
\hline Ricefields & $10.0(3.3-30.3)^{\mathrm{b}}$ & $2.7(1.9-3.7)^{\mathrm{b}}$ & 0.239 \\
Pools & $3.1(2.0-4.8)^{\mathrm{b}}$ & $26.9(8.2-87.6)^{\mathrm{a}}$ & 0.027 \\
Puddles & $47.7(29.5-77.1)^{\mathrm{b}}$ & $5.00(2.6-9.7)^{\mathrm{b}}$ & 0.050 \\
Man-made pits & $23.8(5.4-104.8)^{\mathrm{b}}$ & - & $\mathrm{n} / \mathrm{a}$ \\
Floodwater & - & $4.3(3.1-6.1)^{\mathrm{b}}$ & $\mathrm{n} / \mathrm{a}$ \\
Stream fringes & - & $5.1(3.0-8.6)^{\mathrm{b}}$ & $\mathrm{n} / \mathrm{a}$ \\
$\mathbf{p}^{*}$ & 0.066 & 0.027 & \\
& & &
\end{tabular}

a, b: different letters in lines $(p<0.05)$ or rows $(p<0.0125)$ indicate significance (in floodplain only comparison between pools and other habitats was run)

*Kruskall-Wallis-Test
Table 5: Univariate analyses of factors associated with Anopheles larval density

\begin{tabular}{|c|c|c|c|c|}
\hline & Odds ratio & $95 \%$ & $\mathbf{C l}$ & $\mathbf{p}$ \\
\hline \multicolumn{5}{|l|}{ Habitat perimeter } \\
\hline $1-10 \mathrm{~m}$ & I & & & \\
\hline $10-100 \mathrm{~m}$ & 0.434 & 0.096 & 1.961 & 0.278 \\
\hline$>100 \mathrm{~m}$ & 0.151 & 0.060 & $0.38 \mathrm{I}$ & $<0.001$ \\
\hline \multicolumn{5}{|l|}{ Vegetation coverage } \\
\hline $0-25 \%$ & I & & & \\
\hline $25-50 \%$ & 0.352 & 0.136 & 0.911 & 0.031 \\
\hline $50-75 \%$ & 0.259 & 0.105 & 0.642 & 0.004 \\
\hline $75-100 \%$ & 0.227 & 0.099 & 0.519 & 0.000 \\
\hline \multicolumn{5}{|l|}{ Tidal water } \\
\hline no & I & & & \\
\hline yes & 0.232 & 0.101 & 0.533 & 0.001 \\
\hline \multicolumn{5}{|l|}{$\begin{array}{l}\text { Deep water body } \\
(>50 \mathrm{~cm})\end{array}$} \\
\hline no & I & & & \\
\hline yes & 0.498 & 0.241 & 0.1 .03 & 0.060 \\
\hline
\end{tabular}

Adult emergence occurred in all habitats but production differed between habitat types for both An. gambiae s.l. ( $\mathrm{p}$ $<0.001)$ and An. coustani s.l. $(\mathrm{p}=0.007)$. Average An. gambiae production was significantly higher in pools than all other habitats except in rice fields at the edge of the floodplain close to the upland. All other habitats were similarly productive (Table 7 and Figure 4). An. coustani s.l. emerged in higher densities than An. gambiae s.l. in all habitat types. An. coustani s.l. production was highest in rice fields at the edge of the floodplain close to the upland followed by pools (Table 7 and Figure 4).

Emergence traps were placed in all habitat types from the beginning of June and rainfall commenced approximately

Table 6: Emergence fauna collected in 715 trap-weeks

\begin{tabular}{|c|c|c|}
\hline Taxa & Total & Average no./week $/ \mathrm{m}^{2}$ \\
\hline Heteroptera & 596 & 1.06 \\
\hline Odonata & 434 & 0.77 \\
\hline Diptera & 105,204 & 187.20 \\
\hline Chironomidae & 83,204 & 148.06 \\
\hline Simuliidae & 1,518 & 2.70 \\
\hline Culicidae & 7,514 & 13.37 \\
\hline Culicinae & 7,201 & 12.81 \\
\hline Anophelinae & 313 & 0.56 \\
\hline Anopheles coustani s.l. & 207 & 0.37 \\
\hline Anopheles gambiae s.l. & 73 & 0.13 \\
\hline Anopheles pharoensis & 13 & 0.02 \\
\hline others & 20 & 0.04 \\
\hline
\end{tabular}




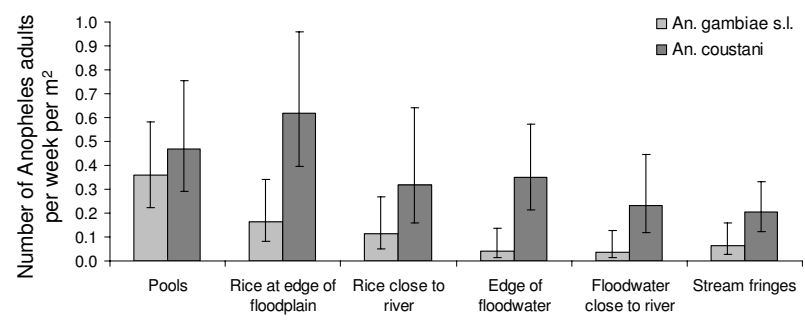

Figure 4

Average adult anopheline densities per week and $\mathbf{m}^{2}$ in different habitat types during the rainy season

2005. Error bars show $95 \%$ confidence intervals.

2 weeks later. Whereas other insects were caught throughout the sampling period (Figure 5) anopheline mosquitoes only started emerging from late July after the first peak in rainfall (Figure 6). Most adult anophelines emerged in August and September (83\% of all An. gambiae and $68 \%$ of all An. coustani) when the highest larval densities were observed (Figure 3 ). The pools produced on average 0.74 (95\% CI 0.31-1.16) An. gambiae s.l. and 1.06 (95\% CI -0.04-2.15)An. coustani s.l. per $\mathrm{m}^{2}$ per week during these two months. Stream fringes, the edge of floodwater and floodwater areas close to the river produced $A n$. gambiae only on a few occasions. Rice fields showed a conspicuous seasonality depending on their location. Rice fields closer to the edge of the floodplains produced An. gambiae adults from the end of August till the end of September whereas none emerged at this time period in rice fields close to the river. In those, adults were only detected at the end of the rainy season in October/November.
Average culicine productivity was low in the beginning of the rainy season and only started to increase from September onwards with an increase of a magnitude in November after the rain had already stopped (Figure 7); $88 \%$ of all culicine mosquitoes were collected from rice fields at the edge of the floodplain close to the upland and $7 \%$ from the pools, the remaining 5\% were collected from floodwater areas and rice fields close to the river.

All habitat types surveyed for insect emergence were similar in $\mathrm{pH}(6.7 ; 95 \% \mathrm{CI} 6.5-6.8)$ and oxygen saturation (92\%; 95\% CI 80-104\%). The average water depth under the floating emergence traps was $8 \mathrm{~cm}(95 \%$ CI $7-9 \mathrm{~cm})$. Other abiotic and biotic characteristics varied significantly (Table 8). Pools, the habitat type with the highest An. gambiae production, were characterized by high average water temperature, very low water conductivity, high turbidity and increased presence of algae. This was the only habitat type that was not tidal. The insect community in these pools was characterized by the highest densities of predatory (carnivorous) organisms like dragon-and damselflies and beetles and high densities of chironomids which serve in their larval stage as food organisms for many fish and predatory invertebrates. Consequently, pools had the highest diversity index. In contrast, floodwater habitats and stream fringes had lower water temperatures and were characterized by high water conductivity, low turbidity and a poor insect diversity.

\section{Discussion}

The identification of aquatic habitats preferably colonized by malaria vectors, and those most productive, remains a

Table 7: Mean adult Anopheles densities per habitat type and odds ratio in comparison to pools

\begin{tabular}{|c|c|c|c|c|c|c|c|}
\hline & \multicolumn{3}{|c|}{ Adult density/m² } & \multicolumn{4}{|c|}{ Regression analyses } \\
\hline & Mean* & & $\mathbf{C l}$ & OR & & $\mathbf{C l}$ & $\mathbf{p}$ \\
\hline Anopheles gambiae s.l. & & & & & & & \\
\hline Pools & 0.371 & 0.229 & 0.599 & 1.000 & & & \\
\hline Rice fields at edge of floodplain close to upland & 0.170 & 0.082 & 0.352 & 0.459 & 0.192 & 1.096 & 0.080 \\
\hline Rice fields close to the river & 0.118 & 0.050 & 0.277 & 0.317 & 0.119 & 0.846 & 0.022 \\
\hline Floodwater close to the edge of the floodplain & 0.042 & 0.013 & 0.139 & 0.114 & 0.032 & 0.411 & 0.001 \\
\hline Floodwater close to the river & 0.040 & 0.012 & 0.130 & 0.107 & 0.030 & 0.385 & 0.001 \\
\hline Stream fringes & 0.066 & 0.027 & 0.165 & 0.179 & 0.064 & 0.502 & 0.001 \\
\hline \multicolumn{8}{|l|}{ Anopheles coustani s.l. } \\
\hline Pools & 0.483 & 0.301 & 0.777 & 1.000 & & & \\
\hline Rice fields at edge of floodplain close to upland & 0.635 & 0.408 & 0.989 & $\mathrm{I} .314$ & 0.686 & 2.515 & 0.410 \\
\hline Rice fields close to the river & 0.329 & 0.164 & 0.660 & 0.681 & 0.293 & 1.582 & 0.372 \\
\hline Floodwater close to the edge of the floodplain & 0.360 & 0.219 & 0.592 & 0.745 & 0.374 & $\mathrm{I} .48 \mathrm{I}$ & 0.401 \\
\hline Floodwater close to the river & 0.238 & 0.123 & 0.461 & 0.493 & 0.218 & 1.112 & 0.088 \\
\hline Stream fringes & 0.209 & 0.128 & 0.341 & 0.431 & 0.218 & 0.854 & 0.016 \\
\hline
\end{tabular}

*GEE were used to calculate mean and $95 \% \mathrm{Cl}$, with site ID as subject units, log linked mosquito densities and habitat type as the factor 


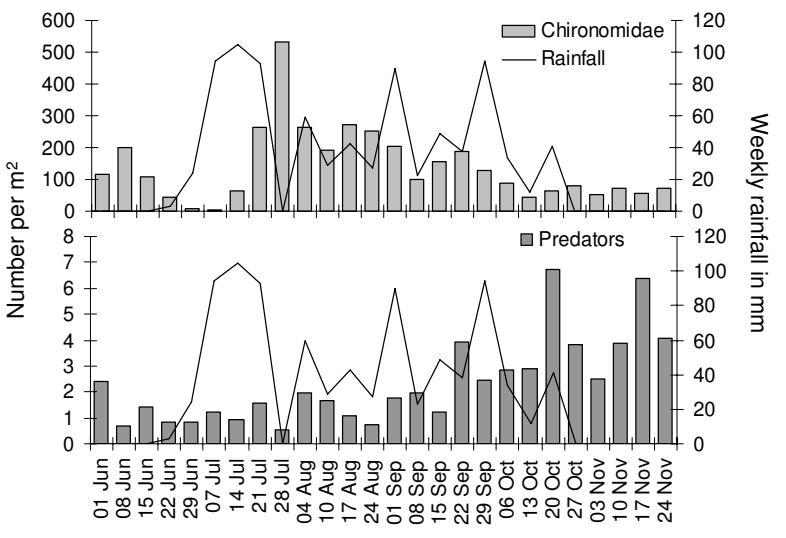

Figure 5

Weekly emergence of chironomids and predatory insects per $\mathrm{m}^{2}$ in relation to rainfall pattern.

challenge since our results show that apparently similar habitats would not always contain anopheline larvae. Only two factors increased the probability of finding anopheline larvae in a habitat; namely the presence of tufts of grass or other short emergent vegetation and the presence of algae. Both factors have been identified to be of importance in a number of other studies throughout Africa [30-34]. The presence of algae in anopheline production remains controversial. Whilst algae can provide a viable food source for Anopheles larvae [32], algae are frequently associated with older habitats which may be less suitable for Anopheles development [30].

The density of larvae was dependent on a number of physical characteristics. Average larval densities decreased with increasing coverage of the water surface by tall vegetation, an observation that has also been made in various other environments throughout Africa $[7,33,35]$ and was historically utilised for mosquito larval source management [7,36-39]. Larval density also decreased when the water was tidal which was the case for the majority of larger $(>100 \mathrm{~m}$ perimeter) and deeper $(>50 \mathrm{~cm})$ habitats. These habitats were also characterized by a high water conductivity $(>2000 \mu \mathrm{S} / \mathrm{cm})$, which specifically reduced the larval density of the primary malaria vectors An. gambiae s.s. and An. arabiensis. These factors probably explain the observation made earlier in a longitudinal survey implemented under operational conditions [20] that larvae were more likely to be found in the first $1 \mathrm{~km}$ stretch from the edge of the floodplain than closer to the river.

Anopheles arabiensis was the most prevalent species of the An. gambiae complex in the study area, which is in agreement with previous findings from dry and humid savannah areas $[40,41]$ but this is not reflected in the indoor collections from houses near the larval habitats, where $A n$. gambiae s.s. dominates [42]. This might be due to the fact

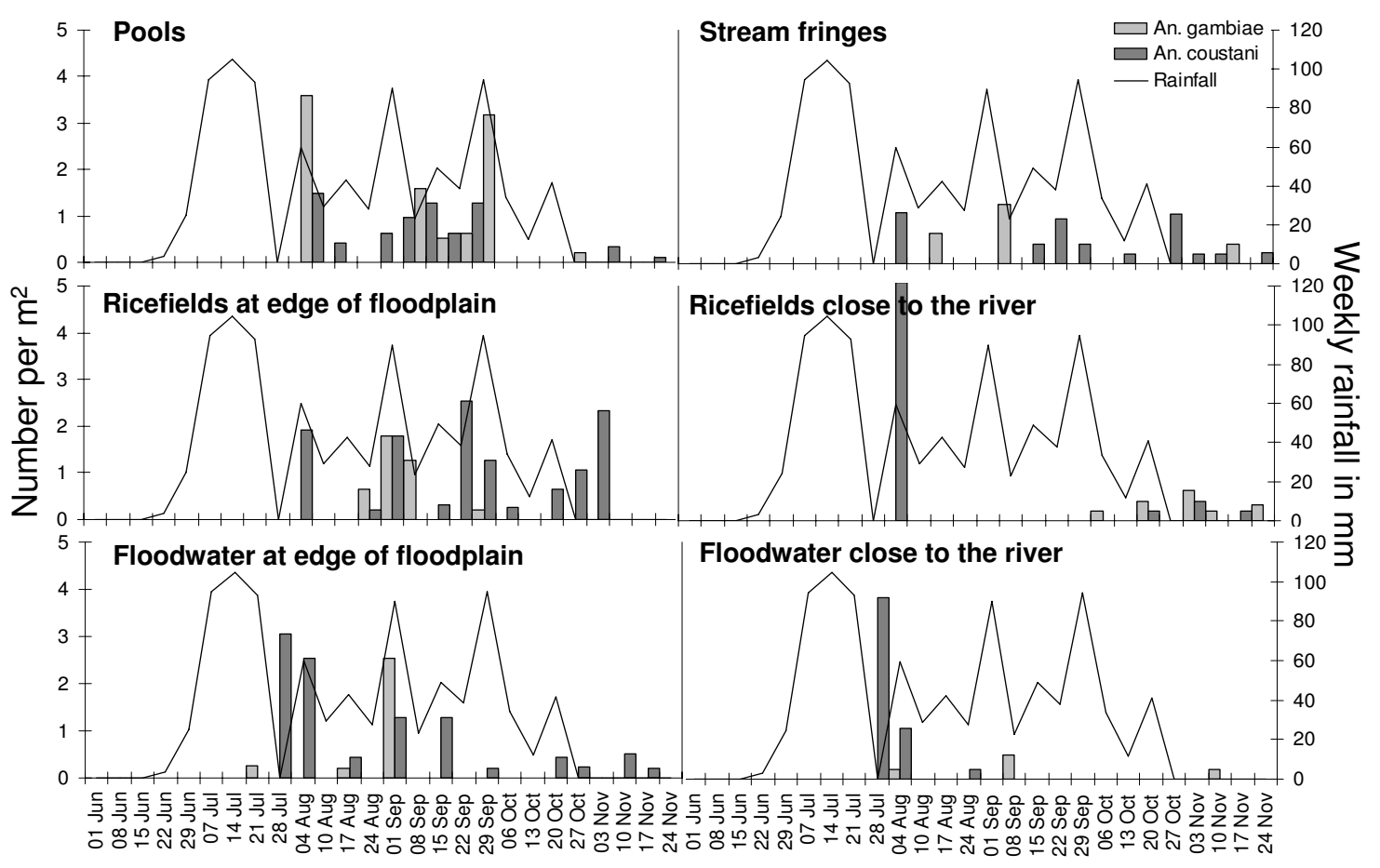

Figure 6

Weekly emergence of An. gambiae and An. coustani per $\mathbf{m}^{2}$ in relation to rainfall pattern. 
Table 8: Abiotic and biotic characteristics of six habitat types surveyed for insect emergence (values represent $\mathrm{means}(95 \% \mathrm{Cl})$ of all sampling events during the rainy season 2005)

\begin{tabular}{|c|c|c|c|c|c|c|c|}
\hline & $\begin{array}{l}\text { Water } \\
\text { temperature } \\
\left({ }^{\circ} \mathrm{C}\right)\end{array}$ & $\begin{array}{l}\text { Conductivity } \\
(\mu \mathrm{S} / \mathrm{cm})\end{array}$ & Turbidity (NTU) & $\begin{array}{l}\text { Chironomida/ } \\
\mathrm{m}^{2} / \text { week }\end{array}$ & $\begin{array}{l}\text { Odonata \& } \\
\text { Coleoptera/m²/ } \\
\text { week }\end{array}$ & $\begin{array}{l}\text { Diversity } \\
\text { Index }\end{array}$ & $\begin{array}{l}\text { Frequency of algae } \\
\text { present in habitat } \\
\text { (\%) }\end{array}$ \\
\hline Pools & $\begin{array}{l}33.2 \\
(31.1-35.5)^{c}\end{array}$ & $\begin{array}{l}323 \\
(227-874)^{a}\end{array}$ & $\begin{array}{l}204 \\
(97-3 \mid 0)^{a, b}\end{array}$ & $\begin{array}{l}166 \\
(125-212)^{a, b}\end{array}$ & $\begin{array}{l}1.18 \\
(0.99-1.38)^{\mathrm{a}}\end{array}$ & $\begin{array}{l}0.5 \\
(0.44-0.56)^{\mathrm{a}}\end{array}$ & 69.9 \\
\hline $\begin{array}{l}\text { Rice close to } \\
\text { upland }\end{array}$ & $\begin{array}{l}28.9 \\
(25.8-32.0)^{\mathrm{a}, \mathrm{b}}\end{array}$ & $\begin{array}{l}3138 \\
(1990-4286)^{b}\end{array}$ & $\begin{array}{l}316 \\
(133-500)^{a}\end{array}$ & $\begin{array}{l}334 \\
(23 \mathrm{I}-439)^{\mathrm{a}}\end{array}$ & $\begin{array}{l}1.11 \\
(0.90-1.32)^{\mathrm{a}}\end{array}$ & $\begin{array}{l}0.36 \\
(0.3 \mathrm{I}-0.42)^{\mathrm{b}}\end{array}$ & 61.6 \\
\hline $\begin{array}{l}\text { Rice far from } \\
\text { upland }\end{array}$ & $\begin{array}{l}30.0 \\
(28.0-32.0)^{b, c}\end{array}$ & $\begin{array}{l}2502 \\
(915-4088)^{a, b}\end{array}$ & $\begin{array}{l}206 \\
(108-305)^{a, b}\end{array}$ & $\begin{array}{l}58 \\
(38-79)^{c}\end{array}$ & $\begin{array}{l}0.32 \\
(0.2 \mathrm{I}-0.44)^{\mathrm{b}}\end{array}$ & $\begin{array}{l}0.40 \\
(0.35-0.44)^{a, b}\end{array}$ & 18.5 \\
\hline $\begin{array}{l}\text { Edge } \\
\text { floodwater }\end{array}$ & $\begin{array}{l}27.6 \\
(25.9-29.4)^{\mathrm{a}, \mathrm{b}}\end{array}$ & $\begin{array}{l}2064 \\
(1608-2519)^{a, b}\end{array}$ & $\begin{array}{l}76 \\
(40-111)^{b}\end{array}$ & $\begin{array}{l}105 \\
(75-134)^{b, c}\end{array}$ & $\begin{array}{l}0.3 \mathrm{I} \\
(0.20-0.4 \mathrm{I})^{\mathrm{b}}\end{array}$ & $\begin{array}{l}0.32 \\
(0.28-0.35)^{b}\end{array}$ & 21.7 \\
\hline $\begin{array}{l}\text { River } \\
\text { floodwater }\end{array}$ & $\begin{array}{l}28.7 \\
(27.1-30.3)^{a, b}\end{array}$ & $\begin{array}{l}1472 \\
(926-2019)^{a, b}\end{array}$ & $\begin{array}{l}72 \\
(38-105)^{b}\end{array}$ & $\begin{array}{l}59 \\
(46-70)^{c}\end{array}$ & $\begin{array}{l}0.21 \\
(0.09-0.32)^{\mathrm{b}}\end{array}$ & $\begin{array}{l}0.35 \\
(0.31-0.38)^{b}\end{array}$ & 10.9 \\
\hline $\begin{array}{l}\text { Stream } \\
\text { fringes }\end{array}$ & $\begin{array}{l}25.7 \\
(23.8-27.5)^{\mathrm{a}}\end{array}$ & $\begin{array}{l}7199 \\
(5618-8778)^{c}\end{array}$ & $\begin{array}{l}102 \\
(59-144)^{\mathrm{b}}\end{array}$ & $\begin{array}{l}149 \\
(117-181)^{\mathrm{a}, \mathrm{b}}\end{array}$ & $\begin{array}{l}0.4 \mathrm{I} \\
(0.3 \mathrm{I}-0.5 \mathrm{I})^{\mathrm{b}}\end{array}$ & $\begin{array}{l}0.33 \\
(0.29-0.37)^{b}\end{array}$ & 47.4 \\
\hline ANOVA $/ \chi^{2}$ & $\begin{array}{l}F(2,125)= \\
6.672 \\
p<0.001\end{array}$ & $\begin{array}{l}F(5,119)= \\
20.65 \\
P<0.001\end{array}$ & $\begin{array}{l}F(5,103)= \\
4.627 \\
p=0.001\end{array}$ & $\begin{array}{l}F(5,709)= \\
\mid 2.735 \\
P<0.00 \mid\end{array}$ & $\begin{array}{l}F(5,709)= \\
35.205 \\
p<0.001\end{array}$ & $\begin{array}{l}F(5,709)= \\
8.090 \\
p<0.001\end{array}$ & $\begin{array}{l}\chi^{2}=151.1, d f=5 \\
P<0.001\end{array}$ \\
\hline
\end{tabular}

Different letters indicate significance $(p<0.05)$ based on Gabriel post-hoc test for ANOVA, insect density was log transformed;

$\mathrm{Chi}^{2}$ test was used for comparing the proportion of time algae were found in a habitat type

that An. arabiensis is a more exophilic mosquito and feeds to a large proportion on cattle which can be found closer to the habitats $[43,44]$. Nevertheless, the dominant Anopheles species in this survey was An. coustani s.l., a mosquito that rests and bites outside [45]. Anopheles coustani and An. pharaoensis are considered secondary vectors of malaria in The Gambia but no published information is available about their role in malaria transmission in the country. Notably, An. coustani and An. pharaoensis represented a large proportion of the sampled anophelines; that is $44 \%$ of the identified larvae and $70 \%$ of adults. Recent studies from Senegal have shown that environmental changes can lead to changes in the vectorial system $[41,46]$ and these may be further impacted if vector control strategies, which focus on indoor host-seeking females lead to a shift in species composition. In such

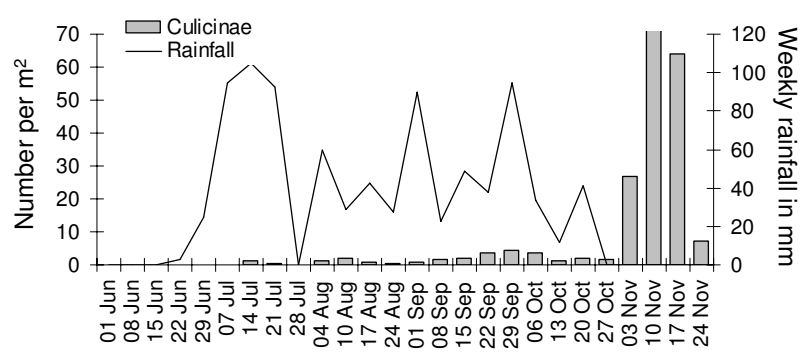

Figure 7

Weekly emergence of culicine mosquitoes per $\mathrm{m}^{2}$ in relation to rainfall pattern. events outdoor biting and resting mosquitoes may increase in importance as vectors of malaria [47].

Most primary and secondary adult malaria vectors emerged in August and September. The average An. gambiae production was significantly higher in confined pools than in all other habitats except in rice fields at the edge of the floodplain close to the upland, which share a number of characteristics with pools since they are more defined than other habitats, have high turbidity and more frequently contain algae. Anopheles coustani emerged in higher densities than An. gambiae in all habitat types surveyed. The overall productivity per $\mathrm{m}^{2}$ of aquatic habitat in The Gambia was very low for vectors and other invertebrates alike. In relatively small and confined An. gambiae habitats in Kenya for example 18-200 larvae were sampled per area sampler (notably the area sampler was much smaller; $78.5 \mathrm{~cm}^{2}$ ), and 1-30 pupae collected per $\mathrm{m}^{2}$ depending on habitat type and season [48]. In the western Kenyan highlands, a one year survey with emergence traps [49] estimated the average productivity of aquatic habitats to be $1.82 \mathrm{An}$. gambiae per $\mathrm{m}^{2}$ per week; 14-times higher than the findings from The Gambia.

Confined habitats were most likely to have high densities of larvae and lead to the greatest number of adults emerging. They were typically characterized by freshwater with low conductivity, high turbidity, presence of algae and the lack of disturbance by tidal water movements. Vectors and other invertebrates alike thrived in this environment. This is probably a result of the protection that these habitats provide from changing environmental impact due to tidal water movement and the high nutrients present in these 
habitats. Freshwater streams ideally have a conductivity between $150-500 \mu \mathrm{S} / \mathrm{cm}$ to support a diverse aquatic life [50]. However, extremely high water conductivity due to high salinity and other dissolved ions, as measured in most habitats in this region of The Gambia, has a negative impact on primary production [51]. Run-off, plants, phyto- and zooplankton and other microorganisms are responsible for the provision of food for all primary consumers (e.g. chironomid and mosquito larvae), which serve as food sources for secondary consumers (e.g. predatory dragon- and damselfly larvae, bugs, fish). The vast floodwater area of this region of the Gambia River is poor in nutrients presenting little food for both, primary and secondary consumers. It is, therefore, not surprising that mosquito larvae were found associated with other invertebrates which are primarily predatory organisms. This extends also to the presence of fish in some habitats. In rice fields for example, the presence of small fish was positively associated with the density of vectors and other invertebrates (OR 2.883, 95\% CI 1.141-7.284, p = 0.025). Invertebrate predators and small fish are natural enemies of mosquito larvae [52-54] and ovipositing mosquitoes are known to avoid habitats colonised by predators $[55,56]$. These apparently contradictory findings may indicate that greater reproductive success can be achieved by ovipositing females laying their eggs in water bodies with predators, where the chance of producing offspring is greater than that found in less salubrious water bodies, where there are no predators. Here water quality is perhaps more important than the presence of predators.

Two aspects affect larval distribution in aquatic habitats; the oviposition choice of a gravid female and the survival of larvae in the aquatic environment. Early instars of anopheline larvae were found in $88 \%$ of all habitats where larvae were present (cases), whilst late instars occurred only in $59 \%$ of sites. This result may indicate that oviposition occurs in a larger number of habitats perceived suitable by the ovipositing female but that the survival of larvae as expressed by larval density depends on factors associated with habitat size, stability and conductivity of water bodies. Another explanation for the wider distribution of early instars could be that the early instar larvae are more readily dispersed by the movement of tidal water than late instars. Binary analyses revealed that the presence of short vegetation and algae at the sampling point was associated with the presence of early, but not late instars, indicating that these factors, or their associated covariates like nutrients, bacteria and volatiles released from the water [57], are important for the adult female seeking oviposition sites, but that additional factors impact on larval survival.

Rice is the staple food for people in The Gambia and in this part of the country rice fields represent the majority of habitats. After the seasonal rains start in June, women plough their fields in the floodplains of the Gambia River and prepare raised beds for growing rice. Two sets of young plants are transplanted to the fields. The first are transplanted early on in the rainy season in paddies close to the landward edge of the floodplain in August. These are the first areas to flood after the soil becomes saturated following several heavy downpours. However, by October, most of them are drying out and the second set of young rice plants are transplanted to fields close to the river from late September to early October. Here the water is largely flowing in from the river. This explains the seasonality in adult emergence observed. Fields closer to the edge of the floodplains produced An. gambiae adults from the end of August until the end of September, whereas fields closer to the river produced adults at the end of the rainy season in October/November. The overall adult productivity over the season was similar in both fields far away and close to the river, which contradicts findings from a far more intensive but smaller study closer to Farafenni which found nearly all adults emerged from rice fields located within $100 \mathrm{~m}$ from the landward edge, away from the river (Jarju, L. personal communication). These contradictory findings suggest that within the smaller study area stronger tides (since it is nearer the river's mouth) may have reduced mosquito production close to the river. Distance from the edge of the floodplain was not a limiting factor either, demonstrating that adults are produced from within the flooded areas and not just on the landward fringe.

Over the entire sampling period, only 33 mosquito pupae were collected with area samplers. This confirms earlier observations [14] that pupae are rare, widely distributed and difficult to sample in the extensive habitats of The Gambia. The use of area samplers did not improve the sampling success in comparison to dipping and therefore cannot be used as a reliable tool to estimate emergence. Generally, the difficulty in sampling vectors in the highly mobile environment in the floodplain of The Gambia, especially closer to the river, needs to be emphasized. The productivity in tidal habitats might have been underestimated in contrast to defined pools using emergence traps since larvae travel with water and might have not emerged under the trap. It is simply far easier to sample mosquitoes in small, defined habitats with higher density per surface area than in large and thinly populated habitats with constant water movement.

\section{Conclusion}

In an extensive habitat survey of an area of $400 \mathrm{~km}^{2}$, irrigated rice fields presented the vast majority of aquatic habitats with a total surface area of $4,300 \mathrm{ha}\left(43 \mathrm{~km}^{2}\right)$, the landward edge of the floodwater accounted for approximately 1000 ha $\left(10 \mathrm{~km}^{2}\right)$ of aquatic habitats whilst in 
total all pools covered a surface area of 2 ha $\left(0.02 \mathrm{~km}^{2}\right)$ only, representing only $0.03 \%$ of the potential mosquito breeding sites [20]. Therefore, highly productive breeding sites, like confined pools, are small in surface area in this part of The Gambia, whereas those with low productivity are large and widely distributed, and can be found throughout the rainy season. The vast majority of potential breeding sites are floodwater areas including extensive swamp rice cultivations over the entire width of the floodplain. All habitat types are equally colonized and even though the majority of sites have low larval density resulting in a low emergence rate, these tidal floodwater areas including rice fields present the majority of surface water in The Gambia. Even though risk factors could be identified for the presence and density of larvae and productivity of habitats, they indicate that anti-larval interventions in this part of The Gambia cannot be targeted in space or time during the rainy season.

\section{Consent}

Persons shown in the photographs have consented to publication.

\section{Competing interests}

The authors declare that they have no competing interests.

\section{Authors' contributions}

UF, SWL, WT and SM designed the study. HS was responsible for the implementation of the study in the laboratory and the field, assisted by SM and EvL. UF analysed the data and drafted the manuscript. All authors read and approved the final manuscript.

\section{Acknowledgements}

We wish to thank the local communities in the study area around Balanghar Ker Nderry for allowing us to sample mosquitoes especially in their rice fields. We thank David Conway and the staff of the Medical Research Council Laboratories for their support and Ebrima Kuate, Tomaring Jadama and Ebrima Manneh for their assistance in the field. Persons shown in the photographs have consented to publication. This study was funded by the National Institute of Health (NIH) Grant No. I UOI Al058250-0I. UF was supported by the Environmental Health Project (EHP) of the United States Agency of International Development (USAID).

\section{References}

I. Killeen GF, Fillinger U, Kiche I, Gouagna LC, Knols BG: Eradication of Anopheles gambiae from Brazil: lessons for malaria control in Africa? Lancet Infect Dis 2002, 2:618-627.

2. Kitron U, Spielman A: Suppression of transmission of malaria through source reduction: antianopheline measures applied in Israel, the United States, and Italy. Rev Infect Dis 1989, I I:39|-406.

3. Russell PF: Man's mastery of malaria London: Oxford University Press; 1955.

4. Shousha AT, Pasha MD: The eradication of Anopheles gambiae from Upper Egypt. Bull World Health Organ 1948, I:309-333.

5. Soper FL, Wilson DB: Anopheles gambiae in Brazil New York: The Rockefeller Foundation; 1943.

6. Utzinger J, Tozan Y, Singer BH: Efficacy and cost-effectiveness of environmental management for malaria control. Trop Med Int Health 200I, 6:677-687.
7. Watson M: African Highway London: John Murray; 1953.

8. Graves PM, Osgood DE, Thomson MC, Sereke K, Araia A, Zerom M, Ceccato P, Bell M, Del Corral J, Ghebreselassie S, Brantly EP, Ghebremeskel T: Effectiveness of malaria control during changing climate conditions in Eritrea, 1998-2003. Trop Med Int Health 2008, 13:218-228.

9. Shililu J, Mbogo C, Ghebremeskel T, Githure J, Novak R: Mosquito larval habitats in a semiarid ecosystem in Eritrea: impact of larval habitat management on Anopheles arabiensis population. Am J Trop Med Hyg 2007, 76:103-II0.

10. Fillinger U, Lindsay SW: Suppression of exposure to malaria vectors by an order of magnitude using microbial larvicides in rural Kenya. Trop Med Int Health 2006, I I:1629-1642.

II. Fillinger U, Ndenga B, Githeko A, Lindsay SW: Integrated malaria vector control with microbial larvicides and insecticide treated nets in the western Kenyan highlands: a controlled trial. Bull World Health Organ 2008 in press.

12. Fillinger U, Kannady K, William G, Vanek MJ, Dongus S, Nyika D, Geissbuhler Y, Chaki PP, Govella NJ, Mathenge EM, Singer BH, Mshinda H, Lindsay SW, Tanner M, Mtasiwa D, de Castro MC, Killeen GF: A tool box for operational mosquito larval control: preliminary results and early lessons from the Urban Malaria Control Programme in Dar es Salaam, Tanzania. Malar J 2008, 7:20.

13. Geissbühler Y, Kannady K, Chaki P, Emidi B, Govella NJ, Mayagaya V, Mtasiwa D, Mshinda H, Lindsay SW, Fillinger U, Tanner M, Castro MC, Killeen GF: Integrated malaria control incorporating microbial larvicides in Dar es Salaam, United Republic of Tanzania. PloS ONE 2009, 4(3):e5I07.

14. Majambere S, Lindsay SW, Green C, Kandeh B, Fillinger U: Microbial larvicides for malaria control in The Gambia. Malar J 2007, 6:76.

15. Malaria country profiles [http://www.afro.who.int/malaria/coun try-profile/gambia.pdf]

16. Clarke SE, Bogh C, Brown RC, Pinder M, Walraven GE, Lindsay SW: Do untreated bednets protect against malaria? Trans $R$ Soc Trop Med Hyg 200I, 95:457-462.

17. Clarke SE, Bogh C, Brown RC, Walraven GE, Thomas CJ, Lindsay SW: Risk of malaria attacks in Gambian children is greater away from malaria vector breeding sites. Trans $R$ Soc Trop Med Hyg 2002, 96:499-506.

18. Bogh C, Lindsay SW, Clarke SE, Dean A, Jawara M, Pinder M, Thomas C): High spatial resolution mapping of malaria transmission risk in the Gambia, west Africa, using LANDSAT TM satellite imagery. Am J Trop Med Hyg 2007, 76:875-88I.

19. NMCP: National Malaria Control Strategic Plan 2002-2007 Gambia Department of State for Health and Welfare; 2002.

20. Majambere S, Fillinger U, Sayer D, Green C, Lindsay SW: Spatial distribution of mosquito larvae and the potential for targeted larval control in the Gambia. Am J Trop Med Hyg 2008, 79: $19-27$.

21. Dongus S, Nyika D, Kannady K, Mtasiwa D, Mshinda H, Fillinger U, Drescher AW, Tanner M, Castro MC, Killeen GF: Participatory mapping of target areas to enable operational larval source management to suppress malaria vector mosquitoes in Dar es Salaam, Tanzania. Int J Health Geogr 2007, 6:37.

22. Gu W, Utzinger J, Novak RJ: Habitat-based larval interventions: a new perspective for malaria control. Am J Trop Med Hyg 2008, 78:2-6.

23. Web-based randomization tool [http://www.randomiza tion.com]

24. Service MW: Mosquito Ecology Second edition. London: Chapman \& Hall; 1993.

25. WHO: Entomological field techniques for malaria control Geneva: World Health Organization; 1992.

26. Scott JA, Brogdon WG, Collins FH: Identification of single specimens of the Anopheles gambiae complex by the polymerase chain reaction. Am J Trop Med Hyg 1993, 49:520-529.

27. Southwood TRE: Ecological methods, with special reference to the study of insect populations London: Chapman and Hall; 1978.

28. Magurran AE: Ecological diversity and its measurement Cambridge: University Press; 1988.

29. Hanley JA, Negassa A, Edwardes MD, Forrester JE: Statistical analysis of correlated data using generalized estimating equations: an orientation. Am J Epidemiol 2003, 157:364-375.

30. Fillinger U, Sonye G, Killeen GF, Knols BG, Becker N: The practical importance of permanent and semipermanent habitats for 
controlling aquatic stages of Anopheles gambiae sensu lato mosquitoes: operational observations from a rural town in western Kenya. Trop Med Int Health 2004, 9:1274-1289.

31. Gimnig JE, Ombok M, Kamau L, Hawley WA: Characteristics of larval anopheline (Diptera: Culicidae) habitats in Western Kenya. J Med Entomol 200I, 38:282-288.

32. Gimnig JE, Ombok M, Otieno S, Kaufman MG, Vulule JM, Walker ED: Density-dependent development of Anopheles gambiae (Diptera: Culicidae) larvae in artificial habitats. J Med Entomol 2002, 39:162-172.

33. Minakawa N, Munga S, Atieli F, Mushinzimana E, Zhou G, Githeko AK, Yan G: Spatial distribution of anopheline larval habitats in Western Kenyan highlands: effects of land cover types and topography. Am J Trop Med Hyg 2005, 73:157-165.

34. Muirhead-Thomson RC: Studies on the breeding places and control of Anopheles gambiae and An. gambiae var. melas in costal districts of Sierra Leone. Bull Entomol Res 1945, 39: $185-252$.

35. Mwangangi JM, Muturi EJ, Shililu JI, Muriu S, Jacob B, Kabiru EW, Mbogo CM, Githure Jl, Novak RJ: Environmental covariates of Anopheles arabiensis in a rice agroecosystem in Mwea, Central Kenya. J Am Mosq Control Assoc 2007, 23:37I-377.

36. Blacklock DB: Studies in rural hygiene in the tropics. The cultivation of dense shade plants as an anti-malaria measure. Ann Trop Med Parasitol 1936, 30:18I-185.

37. Hacket LW, Russell PF, Scharff JW, White R: The present use of naturalistic measures in the control of malaria. Bulletin of the Health Organization of the League of Nations 1938, 7:1016-1064.

38. Hancock G: The mosquitoes of Namanve swamp, Uganda. J Anim Ecology 1934, 3:204-221.

39. Muirhead-Thomson RC: Mosquito behaviour in relation to malaria transmission and control in the tropics London: Edward Arnold \& Co; 1951.

40. Coetzee M, Craig M, le Sueur D: Distribution of African malaria mosquitoes belonging to the Anopheles gambiae complex. Parasitol Today 2000, 16:74-77.

41. Dia I, Konate L, Samb B, Sarr JB, Diop A, Rogerie F, Faye M, Riveau $G$, Remoue $F$, Diallo $M$, Fontenille $D$ : Bionomics of malaria vectors and relationship with malaria transmission and epidemiology in three physiographic zones in the Senegal River Basin. Acta Trop 2008, 105: 145-153.

42. Kirby MJ, Green C, Milligan PM, Sismanidis C, Jasseh M, Conway DJ, Lindsay SW: Risk factors for house-entry by malaria vectors in a rural town and satellite villages in The Gambia. Malar J 2008, 7:2.

43. Bogh C, Clarke SE, Pinder M, Sanyang F, Lindsay SW: Effect of passive zooprophylaxis on malaria transmission in The Gambia. J Med Entomol 200I, 38:822-828.

44. Lindsay SW, Wilkins HA, Zieler HA, Daly RJ, Petrarca V, Byass P: Ability of Anopheles gambiae mosquitoes to transmit malaria during the dry and wet seasons in an area of irrigated rice cultivation in The Gambia. J Trop Med Hyg I99I, 94:3। 3-324.

45. Gillies MT, DeMeillon B: The Anophelinae of Africa south of the Sahara (Ethiopian zoogeographical region) 2nd edition. Johannesburg: South African Institute of Medical Research; 1968.

46. Dia I, Diop T, Rakotoarivony I, Kengne P, Fontenille D: Bionomics of Anopheles gambiae Giles, An. arabiensis Patton, An. funestus Giles and An. nili (Theobald) (Diptera: Culicidae) and transmission of Plasmodium falciparum in a Sudano-Guinean zone (Ngari, Senegal). J Med Entomol 2003, 40:279-283.

47. Geissbuhler Y, Chaki P, Emidi B, Govella NJ, Shirima R, Mayagaya V, Mtasiwa D, Mshinda H, Fillinger U, Lindsay SW, Kannady K, de Castro MC, Tanner M, Killeen GF: Interdependence of domestic malaria prevention measures and mosquito-human interactions in urban Dar es Salaam, Tanzania. Malar J 2007, 6: 126.

48. Mutuku FM, Bayoh MN, Gimnig JE, Vulule JM, Kamau L, Walker ED, Kabiru E, Hawley WA: Pupal habitat productivity of Anopheles gambiae complex mosquitoes in a rural village in western Kenya. Am J Trop Med Hyg 2006, 74:54-6I.

49. Munga S, Minakawa N, Zhou G, Mushinzimana E, Barrack OO, Githeko AK, Yan G: Association between land cover and habitat productivity of malaria vectors in Western Kenyan highlands. Am J Trop Med Hyg 2006, 74:69-75.

50. Behar S: Testing the waters: chemical and physical vital signs of a river Sharon Montpelier: River Watch Network; 1997.

5I. Closs G, Downes B, Boulton A: Freshwater ecology Blackwell Publishing; 2003.
52. Das PK, Amalraj DD: Biological control of malaria vectors. Indian J Med Res 1997, 106: 174-197.

53. Morales ME, Wesson DM, Sutherland IW, Impoinvil DE, Mbogo CM, Githure JI, Beier JC: Determination of Anopheles gambiae larval DNA in the gut of insectivorous dragonfly (Libellulidae) nymphs by polymerase chain reaction. J Am Mosq Control Assoc 2003, 19:163-165.

54. Pates H, Curtis C: Mosquito behavior and vector control. Annu Rev Entomol 2005, 50:53-70.

55. Louca V, Martyn CL, Green C, Majambere S, Fillinger U, Lindsay SW: Role of fish as predators of mosquito larvae on the floodplain of the Gambia River. J Med Entomol 2009 in press.

56. Munga S, Minakawa N, Zhou G, Barrack OO, Githeko AK, Yan G: Effects of larval competitors and predators on oviposition site selection of Anopheles gambiae sensu stricto. J Med Ento$\mathrm{mol}$ 2006, 43:22I-224.

57. Bentley MD, Day JF: Chemical ecology and behavioral aspects of mosquito oviposition. Annu Rev Entomol 1989, 34:40I-42I.
Publish with Bio Med Central and every scientist can read your work free of charge

"BioMed Central will be the most significant development for disseminating the results of biomedical research in our lifetime. "

Sir Paul Nurse, Cancer Research UK

Your research papers will be:

- available free of charge to the entire biomedical community

- peer reviewed and published immediately upon acceptance

- cited in PubMed and archived on PubMed Central

- yours - you keep the copyright

Submit your manuscript here:

http://www.biomedcentral.com/info/publishing_adv.asp
BioMedcentral 